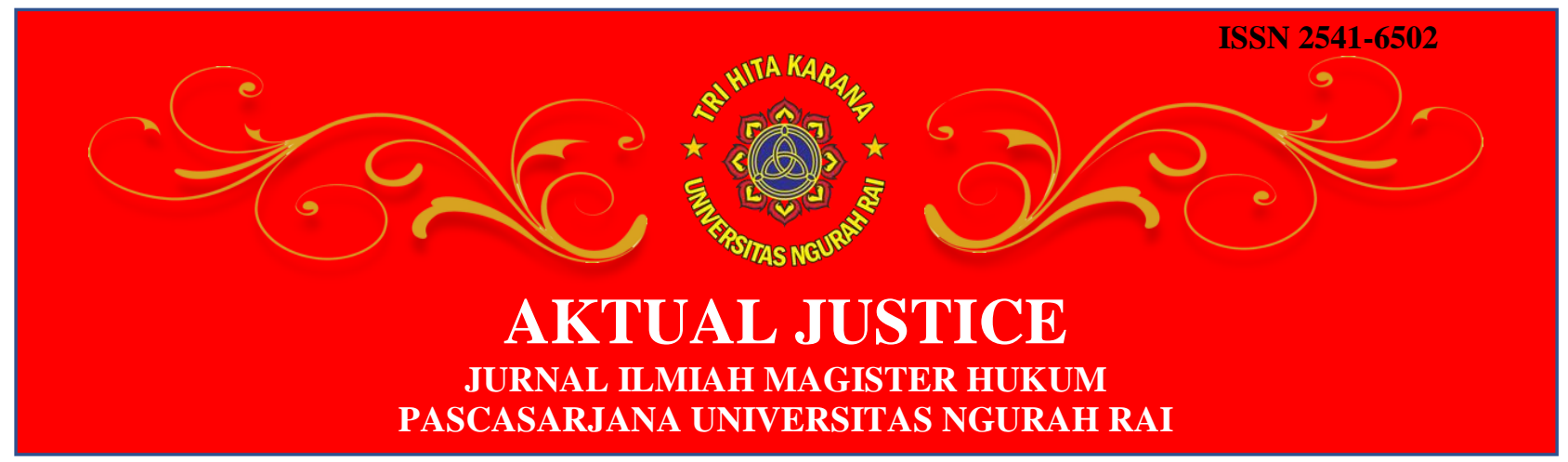

\title{
TERMINOLOGI KEJAHATAN DALAM HUKUM PIDANA INTERNASIONAL
}

\author{
Dewi Bunga \\ Dosen Fakultas Hukum Institut Hindu Dharma Negeri (IHDN) Denpasar, \\ E-mail : Bunga8287@gmail.com
}

\begin{abstract}
The globalization of crime incised a social reality where crimes can be committed across national borders and have an impact not only on the people of a country, but on the international community. Theoretically, there are several terms that are known to describe acts which are called crimes under international law, namely international crimes, transnational crimes, and national crimes with international dimensions. International crimes are crimes that threaten both directly and indirectly to international peace and security, affect many countries and have universal jurisdiction. The qualification of international crimes refers to crimes regulated in the Rome Statute of the International Criminal Court (Rome Statute circulated as document A / CONF.183 / 9 of 17 July 1998), namely crimes of genocide; crimes against humanity; war crimes; and crime of aggression. Transnational crimes are transnational crimes regulated in international conventions.
\end{abstract}

Keywords: international criminal law, international crimes and transnational crimes.

\begin{abstract}
Abstrak
Globalisasi kejahatan menorehkan kenyataan sosial dimana kejahatan dapat dilakukan secara lintas batas negara dan membawa dampak bukan hanya pada masyarakat di suatu negara saja, namun pada masyarakat internasional. Secara teoretis, ada beberapa istilah yang dikenal untuk menggambarkan perbuatan yang disebut sebagai kejahatan menurut hukum internasional yakni kejahatan internasional, kejahatan transnasional, dan kejahatan nasional yang berdimensi internasional. Kejahatan internasional adalah kejahatan yang mengancam baik secara langsung maupun tidak langsung terhadap perdamaian dan keamanan internasional, berdampak pada banyak negara dan memiliki yurisdiksi universal. Kualifikasi kejahatan internasional merujuk pada kejahatan yang diatur dalam Rome Statute of the International Criminal Court (Rome Statute circulated as document A/CONF.183/9 of 17 July 1998) yakni kejahatan genosida; kejahatan terhadap kemanusiaan; kejahatan perang; dan kejahatan agresi. Kejahatan transnasional merupakan kejahatan lintas negara yang diatur dalam konvensi internasional.
\end{abstract}

Kata kunci: hukum pidana internasional, kejahatan internasional dan kejahatan transnasional. 


\section{Pendahuluan}

Globalisasi kejahatan menyebabkan kejahatan dilakukan tanpa mengenal batas wilayah negara. Muladi dan Diah Sulistyani R.S.1 menjelaskan bahwa akselarasi transportasi, komunikasi dan informasi modern melahirkan globalisasi teknologi yang berpengaruh terhadap globalisasi kejahatan (globalization of crime). Kebijakan hukum pidana (criminal policy) yang dapat dilakukan dalam menanggulangi hal tersebut adalah dengan warmakingcriminology or harm creating on crime yang bersifat bermusuhan (adversarialism) sebagai pendekatan represif dan dikombinasikan dengan pendekatan preventif mutualisme atau kebersamaan atas dasar peacemaking criminology.

Secara teoritis ada beberapa istilah yang dikenal untuk menggambarkan perbuatan yang disebut sebagai kejahatan menurut hukum internasional yaitu:

a. Kejahatan internasional yakni kejahatan yang peristiwanya bersifat internasional, lintas batas negara dan menyangkut kepentingan lebih dari satu negara.

b. Kejahatan transnasional yakni kejahatan yang sebenarnya adalah kejahatan nasional, namun mengandung aspek lintas batas negara.

c. Kejahatan nasional yang berdimensi internasional. Dimensi internasional tersebut meliputi keberlakuan hukum pidana nasional, akibat kejahatan, subjek hukum (baik pelaku maupun korban) yang berada di luar batas-batas wilayah negaranya, atau kombinasi dari elemen-elemen tersebut. ${ }^{2}$

${ }^{1}$ Muladi dan Diah Sulistyani R.S. (2016). Kompleksitas Perkembangan Tindak Pidana dan Kebijakan Kriminal, Bandung: Alumni, h. 24.

2 Parthiana, I.W. (2006). Hukum Pidana Internasional, Bandung: Yrama Widya, h. 3133. 
Kajian mengenai kejahatan dalam hukum pidana internasional sangat berguna dalam menentukan ketentuan khusus dalam penegakan hukumnya.

\section{Metode Penelitian}

Metode penelitian dalam tulisan ini adalah penelitian yuridis normatif dengan menggunakan study kepustakaan.

\section{Hasil Dan Pembahasan}

\section{a. Terminologi Kejahatan Internasional}

Kejahatan internasional merujuk pada kejahatan yang diatur dalam Rome Statute of the International Criminal Court (Rome Statute circulated as document A/CONF.183/9 of 17 July 1998). Dalam Pasal 5 ayat (1) dinyatakan:

The jurisdiction of the Court shall be limited to the most serious crimes of concern to the international community as a whole. The Court has jurisdiction in accordance with this Statute with respect to the following crimes:

(a) The crime of genocide;

(b) Crimes against humanity;

(c) War crimes;

(d) The crime of aggression.

Yurisdiksi Mahkamah terbatas pada kejahatan luar biasa yang menyangkut masyarakat internasional secara keseluruhan. Mahkamah mempunyai yurisdiksi sesuai dengan Statuta berkenaan dengan kejahatan-kejahatan berikut:

(a) Kejahatan genosida;

(b) Kejahatan terhadap kemanusiaan;

(c) Kejahatan perang;

(d) Kejahatan agresi (translasi oleh peneliti). 
Unsur kejahatan internasional meliputi ancaman secara langsung atau tidak langsung terhadap perdamaian dan keamanan dunia serta menimbulkan guncangan pada hati nurani manusia, perilaku yang mempengaruhi lebih dari satu negara, atau mempengaruhi perilaku termasuk warga negara dari lebih dari satu negara dan sarana dan metode tersebut melampaui batas-batas nasional serta unsur diperlukan adanya kerjasama antar negara dalam melaksanakan penegakan hukum terhadap tindak pidana ini. Perbedaan antara kejahatan internasional dan kejahatan transnasional terletak pada unsur-unsur internasional yang tidak dimiliki oleh tindak pidana transnasional. Unsur internasional tersebut adalah ancaman langsung terhadap perdamaian dan keamanan dunia, ancaman tidak langsung terhadap perdamaian dan keamanan dunia serta perbuatan itu mengguncangkan perasaan kemanusiaan."3International Law Commission ${ }^{4}$ mendeskripsikan mengenai kejahatan yang melanggar perdamaian dan keamanan manusia atau"crimes against the peace and security of mankind, yakni:

a. Crimes of aggression: An individual who, as leader or organizer, actively participates in or order the planning, prepararin, initiation, or waging of aggression committed by a state.

b. Crime of genocide: Any act committed with intent to destroy, in whole of in part, a national, ethnic, racial, or religious group.

c. Crime against humanity: Particularly repulsive offenses constituting a serious attact on human dignity or grave humiliation or degradation of one or more human beings. These crimes are not isolated or sporadic events, but are part either of a government policy or of a wide systematic partice of atrocities tolerated or condoned by a government, including murder, extermination, tortune, rape, and political, racial, or religious persecution and human rights violations.

d. Crimes against United Nations and associated personnel: Crimes committed intentionally and in a systematic manner or on a large scale against United Nations and associated personnel involved in a UN

${ }^{3}$ Agustina, S. (2006). Hukum Pidana Internasional Dalam Teori \& Praktek. Padang: Andalas University Press, h. 74.

${ }^{4}$ Chambliss, W dan Hass, A. (2012). Criminology: Connecting Theory, Research, and Practice. New York: McGraw-Hill, h. 363. 
operation with a view to preventing or impeding that operation from fulfilling its mandate, including murder, kidnapping, and attect upon the official premises.

e. War crime: A systematic or large-scale violation of international humanitarian law, including willful killing, tortune, or in human treatment; willfully causing great suffering or serious injury to body or health: extensive destruction and appropriation of property not justified by military necessity; compelling a prisioner of war or othe protected person too serve in the forces of a hostile power; willfully depriving a prisoner of war or other protected person to the rights of fair and regular trial; unlawful deportation, transfer, or confinement of protected persons; taking of hostages; making the civilian population or individual civilians the object of attact; anusing methods or means of warfare not justified by militaru necessity with the intent to cause widespread, long-term, and sever damage to the natural environment and thereby gravely prejudice the health or survavil of the population.

a. Kejahatan agresi: Seseorang yang, sebagai pemimpin atau penyelenggara, secara aktif berpartisipasi atau dalam hal perencanaan, persiapan, inisiasi, atau serangan agresi yang dilakukan oleh sebuah negara.

b. Kejahatan genosida: Setiap tindakan yang dilakukan dengan maksud untuk menghancurkan, secara keseluruhan, merupakan kelompok nasional, etnis, ras, atau agama.

c. Kejahatan terhadap kemanusiaan: Pelanggaran yang sangat menjijikkan merupakan pelanggaran serius terhadap martabat manusia atau penghinaan atau degradasi serius satu atau lebih martabat manusia. Kejahatan-kejahatan ini tidak terisolasi atau kejadian sporadis, namun merupakan bagian dari kebijakan pemerintah atau sebagian dari kekejaman sistematis yang ditoleransi atau dimaafkan oleh pemerintah, termasuk pembunuhan, pemusnahan, penyiksaan, pemerkosaan, dan penganiayaan politik, rasial, atau agama dan pelanggaran hak asasi manusia

d. Kejahatan terhadap Perserikatan Bangsa-Bangsa dan personil terkait: Kejahatan dilakukan secara sengaja dan secara sistematis atau dalam skala besar melawan Perserikatan Bangsa-Bangsa dan personil terkait yang terlibat dalam operasi PBB dengan maksud untuk mencegah atau menghambat operasi tersebut untuk memenuhi mandatnya, termasuk pembunuhan, penculikan, dan mencapai tempat resmi.

e. Kejahatan perang: Pelanggaran hukum humaniter internasional yang sistematis atau berskala besar, termasuk pembunuhan, penyiksaan, atau perlakuan manusia yang disengaja; dengan 
sengaja menyebabkan penderitaan atau luka serius pada tubuh atau kesehatan: kehancuran dan perampasan harta yang tidak dibenarkan oleh kebutuhan militer; Memohon prisioner perang atau orang yang dilindungi juga bertindak dalam kekuatan yang bermusuhan; dengan sengaja merampas narapidana perang atau orang yang dilindungi lainnya atas hak pengadilan yang adil dan teratur; deportasi, pengalihan, atau pengurungan orang-orang yang dilindungi secara tidak sah; mengambil sandera; membuat warga sipil atau individu sipil menjadi sasaran; metode atau cara perang yang tidak bisa dibenarkan yang tidak dibenarkan oleh kebutuhan militaru dengan maksud untuk menyebabkan kerusakan lingkungan yang luas, jangka panjang, dan rusak terhadap lingkungan alam dan dengan demikian sangat merugikan kesehatan atau kelangsungan populasi (translasi oleh peneliti).

Romli Atmasasmita ${ }^{5}$ mengatakan bahwa ada satu unsur pokok yang membedakan satu perbuatan sebagai kejahatan internasional atau bukan, yaitu bahwa tindakan tersebut harus mengandung unsur transnasional atau internasional yang salah satunya adalah lintas batas teritorial (transboundaries), di samping juga unsur kebutuhan akan kerjasama antar negara (necessity element). Pemberian status sebagai kejahatan internasional sangat bergantung dari dua faktor yaitu:

a. Tindakan itu sudah merupakan tindak pidana yang sangat membahayakan kepentingan masyarakat internasional (serious crimes of international cocern), sehingga setiap negara memiliki kewenangan ntuk mengadili tindak pidana itu, tanpa memperhatikan tempat terjadinya tindak pidana itu.

b. Tindak pidana tersebut merupakan wewenang penuh pengadilan pidana internasional. ${ }^{6}$

5 Atmasasmita, R. (1995), Pengantar Hukum Pidana Internasional. Bandung : Bandung, h. 50

${ }_{6}$ Atmasasmita, R. (1997). Kejahatan Narkotika Transnasional Dalam Sistem Hukum Pidana Indonesia. Bandung: Citra Aditya Bakti, Bandung, h. 82 
Dalam terminologi mengenai kejahatan internasional, ditemukan pula istilah jus cogens dan obligatio erga omnes. Mengenai hal tersebut, $\mathrm{M}$. Cherif Bassiouni" mengatakan "International crimes that rise to the level of jus cogens constitute obligatio erga omnes which are inderogable" (Kejahatan internasional yang naik ke tingkat jus cogens merupakan kewajiban erga omnes yang tidak dapat dipisahkan (translasi oleh peneliti)). Lebih lanjut dikatakan "Jus cogens refers to the legal status that certain international crimes reach, and obligatio erga omnes pertains to the legal implications arising out of a certain crime's characterization as jus cogens." 8 (Jus cogens mengacu pada status hukum yang dicapai kejahatan internasional tertentu, dan kewajiban erga omnes berkaitan dengan implikasi hukum yang timbul dari karakterisasi kejahatan tertentu sebagai jus cogens (translasi oleh peneliti)).

Penegakan hukum terhadap hukum pidana internasional oleh $\mathrm{M}$. Cherif Bassiouni" dikatakan "Historically, international criminal law conventions have focused on the use of the indirect enforcement system, which depends on national criminal justice systems as well as the effectiveness of interstate criminal justice capabilities." (Secara historis, konvensi hukum pidana internasional berfokus pada penggunaan sistem penegakan tidak langsung, yang bergantung pada sistem peradilan pidana nasional serta efektivitas kemampuan peradilan pidana antar negara (translasi oleh peneliti)).

\section{b. Terminologi Kejahatan Transnasional}

7 Bassiouni, M.C. (1996). “International Crimes: Jus Cogens and Obligatio Erga Omnes", Law and Contemporary Problems, Vol. 59, No. 4, Accountability for International Crimes and Serious Violations of Fundamental Human Rights (Autumn, 1996), pp. 63-74, h. 63 .

8 Ibid.

9 Bassiouni, M.C. (2010). "Crimes Against Humanity: The Case for a Specialized Convention", 9 Wash. U. GlobalStud. L. Rev. 575 (2010), h. 591. 
Menurut Mueller sebagaimana dikutip oleh Neil Boister ${ }^{10}$ menyebutkan 'transnational crime' is a criminological rather than a juridical term, coined by the UN Crime Prevention and Criminal Justice Branch 'in order to identify certain criminal phenomena transcending international borders, transgressing the laws of several states or having an impact on another country' ('kejahatan transnasional' adalah istilah kriminologis dan bukan yuridis, yang diciptakan oleh UN Crime Prevention and Criminal Justice Branch' 'untuk mengidentifikasi fenomena kriminal tertentu yang melampaui batas-batas internasional, yang melanggar hukum beberapa negara atau berdampak pada negara lain').

Kejahatan transnasional merupakan kejahatan yang terjadi lintas batas negara dan tunduk pada lebih dari satu yurisdiksi negara. ${ }^{11 K e j a h a t a n}$ transnasional juga disebut sebagai "crime of international concern" atau treaty crime yang melibatkan lebih dari satu yurisdiksi nasional dan tunduk pada kota, bukan yurisdiksi internasional. ${ }^{12}$ Definisi hukum dari kejahatan transnasional dapat dilihat pada Pasal 3 ayat (2) United Nations Convention against Transnational Organized Crime (General Assembly resolution 55/25 of 15 November 2000) atau yang sering disebut dengan The Palermo Convention yang menyatakan sebagai berikut:

For the purpose of paragraph 1 of this article, an offence is transnational in nature if:

(a) It is committed in more than one State;

(b) It is committed in one State but a substantial part of its preparation, planning, direction or control takes place in another State;

(c) It is committed in one State but involves an organized criminal group that engages in criminal activities in more than one State; or

10 Boister, N. (2003). “Transnational Criminal Law'?”. EJIL (2003), Vol. 14 No. 5, 953-976, h. 954.

${ }^{11}$ Hieriej, E.O.S. (2009). Pengantar Hukum Pidana Internasional, Jakarta: Erlangga, h. 48.

12 Hauck, P and Peterke, S. (2016). Internasional Law and Transnational Organised Crime. Oxford: Oxford University Press, h. 17. 
(d) It is committed in one State but has substantial effects in another State.

Untuk tujuan ayat 1 Pasal ini, kejahatan bersifat transnasional jika:

(a) Dilakukan di lebih dari satu negara;

(b) Dilakukan di satu negara namun sebagian besar persiapan, perencanaan, arahan atau penguasaannya dilakukan di Negara lain;

(c) Dilakukan di satu Negara tetapi melibatkan kelompok penjahat terorganisir yang melakukan kegiatan kriminal di lebih dari satu Negara Bagian; atau

(d) Dilakukan di satu Negara namun memiliki dampak substansial di Negara lain.

The Palermo Convention merupakan perjanjian internasional yang memiliki spektrum yang luas dan membutuhkan kerjasama internasional. Mengenai hal ini Giulio Illuminati ${ }^{13}$ mengatakan:

The Palermo Convention provides a broad spectrum of cooperation instruments. Among others, it is worth mentioning mutual assistance in the enforcement of coercive measures (arrest, seizure, confiscation); the rules for establishing jurisdiction over the offence and coordinating state actions in this respect; the improvement in mutual assistance in taking evidence and providing information; the establishment of joint investigative bodies; the conclusion of agreements on the use of special investigative techniques; and the establishment of channels of communications between the competent authorities.

(Konvensi Palermo menyediakan spektrum yang luas dari instrumen kerjasama. Antara lain, perlu disebutkan mengenai bantuan timbal balik dalam penegakan tindakan pemaksaan (penangkapan, perampasan, penyitaan); peraturan untuk menetapkan yurisdiksi atas kejahatan dan mengkoordinasikan tindakan negara dalam hal ini; peningkatan bantuan timbal balik dalam mengambil barang bukti dan memberikan informasi; pembentukan badan investigasi bersama; kesimpulan kesepakatan penggunaan teknik investigasi khusus; dan pembentukan saluran komunikasi antara pihak yang berwenang.

The National Institute of Justice ${ }^{14}$ memberikan definisi mengenai transnational crime sebagai "the criminal activities of individuals and groups who

13 Illuminati, G. (2013). “Transnational Inquiries in Criminal Matters and Respect for Fair Trial Guarantees", Stefano Ruggeri (ed.), 2013, Transnational Inquiries and the Protection of Fundamental Rights in Criminal Proceedings A Study in Memory of Vittorio Grevi and Giovanni Tranchina, New York: Springer, h. 19.

14 Chambliss, W dan Hass, A, op.cit., h. 358. 
commit illegal activities that cross national borders. Transnational crimes are typically perpetrated by organized criminal groups that use violence, bribery, and corruption to carry put their illegal enterprises." (tindakan kejahatan yang dilakukan oleh individu-individu atau kelompok-kelompok yang melakukan kegiatan illegal secara lintas batas negara. Kejahatan transnasional dilakukan oleh kelompok kejahatan yang terorganisasi dengan menggunakan kekerasan, penyuapan, dan korupsi untuk melakukan usaha illegal mereka (translasi oleh peneliti)).

Aspek transnasional dalam kejahatan bertendensi dilakukan secara terorganisir. Pada tahun 1995, definisi kerja dari Council of the European Union merupakan upaya pada tataran praktik kepolisian Eropa untuk memberikan fenomena kejahatan terorganisasi transnasional secara taktis dan kriminatif secara bermanfaat. Berdasarkan Eropean Council (UE/12247/1Rev) sebagaimana dikutip oleh Pierre Hauck and Sven Peterke, kejahatan terorganisir dianggap terdiri dari perilaku yang memenuhi kriteria 1,3,5 dan 11 dalam daftar berikut, ditambah setidaknya dua lagi:

1. an association of more than two people...

2. who each perform individual tasks assigned to them ...

3. for a long or undefined period of time (and indication of stability and potential permanence) ...

4. using specific methods of discipline and control,

5. where the persons are suspected of having committed serious crimes ...

6. at the international level ...

7. using violence and other means of intimidation,

8. using commercial or commerce-like structures,

9. committing money laundering,

10. influencing politics, the media, public administration, the justice system, or the economy and/or

11. motivated by the accumulation of money or power. ${ }^{15}$

1. sebuah perkumpulan lebih dari dua orang ...

${ }^{15}$ Hauck, P and Peterke, S, op.cit., h. 25-26. 
2. siapa yang masing-masing melakukan tugas-tugas individu yang ditugaskan kepada mereka ...

3. untuk jangka waktu yang panjang atau tidak terdefinisi (dan indikasi stabilitas dan ketetapan potensial) ...

4. menggunakan metode disiplin dan kontrol khusus,

5. di mana orang-orang dicurigai telah melakukan kejahatan berat ...

6. di tingkat internasional ...

7. menggunakan kekerasan dan cara intimidasi lainnya,

8. menggunakan struktur komersial atau perdagangan,

9. melakukan tindak pidana pencucian uang,

10. mempengaruhi politik, media, administrasi publik, sistem peradilan, atau ekonomi dan / atau

11. termotivasi oleh akumulasi uang atau kekuasaan.

Menurut Pierre Hauck and Sven Peterke "Organised crime may and often does have an international aspect."16 (Kejahatan terorganisir mungkin dan seringkali memang memiliki aspek internasional (translasi oleh peneliti)).

\section{Kesimpulan}

Kejahatan internasional adalah kejahatan yang mengancam perdamaian dan keamanan internasional, berdampak luas dan memiliki yurisdiksi universal. Kualifikasi kejahatan internasional merujuk pada kejahatan yang diatur dalam Rome Statute of the International Criminal Court (Rome Statute circulated as document A/CONF.183/9 of 17 July 1998). Kejahatan transnasional merupakan kejahatan lintas negara yang diatur dalam konvensi internasional.

\section{Daftar Pustaka}

Agustina. (2006). Hukum Pidana Internasional Dalam Teori E Praktek. Padang: Andalas University Press.

16 Hauck, P and Peterke, S, op.it h. 16. 
Chambliss, W dan Hass, A. (2012). Criminology: Connecting Theory, Research, and Practice, New York: McGraw-Hill.

Hieriej, E.O.S. (2009). Pengantar Hukum Pidana Internasional. Jakarta : Erlangga.

Hauck, P and Peterke, S. (2016). Internasional Law and Transnational Organised Crime. Oxford : Oxford University Press.

Muladi dan Sulistyani, D. (2016). Kompleksitas Perkembangan Tindak Pidana dan Kebijakan Kriminal, Bandung: Alumni.

Parthiana, I. W. (2006). Hukum Pidana Internasional. Bandung: Yrama Widya.

Atmasasmita, R. (1995). Pengantar Hukum Pidana Internasional. Bandung: Eresco.

. (1997). Kejahatan Narkotika Transnasional Dalam Sistem Hukum Pidana Indonesia. Bandung: Citra Aditya Bakti.

Ruggeri, Stefano(ed.). (2013). Transnational Inquiries and the Protection of Fundamental Rights in Criminal Proceedings A Study in Memory of Vittorio Grevi and Giovanni Tranchina. New York: Springer.

Bassiouni, M. Cherif. (1996). “International Crimes: Jus Cogens and Obligatio Erga Omnes", Law and Contemporary Problems, Vol. 59, No. 4, Accountability for International Crimes and Serious Violations of Fundamental Human Rights. Autumn.

. (2020)“Crimes Against Humanity: The Case for a Specialized Convention”, 9 Wash. U. GlobalStud. L. Rev. 575.

Neil Boister. (2003).'Transnational Criminal Law'?” EJIL. Vol. 14 No. 5, 953976. 